\title{
Importance of Synergistic Value in the Context of Business Combination: A Case Study From Turkey
}

\author{
Gurbuz Gokcen \\ Marmara University, Istanbul, Turkey \\ Ozgur Teraman \\ Istanbul Aydın University, Istanbul, Turkey
}

\begin{abstract}
Considering International Financial Reporting Standards (henceforth IFRS), although fair value is suggested in the conceptual framework and related standards, concept of measurement is used instead of concept of valuation. Determining the fair value of the acquiree specific into business combination, is needed to identify the fair value of the valuation made beyond the measurement of either monetary items or non-monetary items in the financial statements. Essential reason of the difference between acquired entity's fair values as a basis of financial reporting standards and valuation standards, the fair value according to IFRS is equivalent to the market value according to International Valuation Standards (henceforth IVS). The fair value in accordance with IVS, the combination of the market value, and the synergistic value of the asset are subject to valuation in terms of special purchaser. When business is concerned, considering parameters such as the position in the industry, brand awareness, intellectual capital, geography, cannot be expected to be equal to the fair value of business which simply consists of market value among market participants. The ultimate aim of the study is to illustrate how to determine synergistic value in the terms of IVS which shows the difference between the market value and fair value. Based on the findings of the study, if acquired assets and liabilities are recognized in accordance with IFRS, goodwill comes out during the acquisition. Though, when fair value is determined based on IVS, goodwill is not found, even profitable business combination is realized. This is the result of considered fair value based on IVS Framework, that is the combination of market value of an asset in question and total synergistic value.
\end{abstract}

Keywords: international valuation standards, international financial reporting standards, business combination, market value, fair value, synergistic value

\section{Brief Introduction}

Valuation is defined as re-measuring when needed the amount recorded in the accounting information system that can be expressed in money. However, it poses with the concept of valuation differences in measurement concepts. Accounting measurements, a set of items in the financial statements are considered as a measuring scale. However, as more advanced stage of the concept of measurement, valuation is an estimation of the value of the entries in the financial statements which are measured.

Gurbuz Gokcen, Ph.D., professor, Department of Accounting and Finance, Marmara University, Istanbul, Turkey.

Ozgur Teraman, Ph.D., assistant professor, Department of Accounting and Finance, Istanbul Aydin University, Istanbul, Turkey.

Correspondence concerning this article should be addressed to Ozgur Teraman, Faculty of Economics and Administrative Sciences, Istanbul Aydin University, Halit Aydin Campus, No. 38, Sefakoy-K.Cekmece, Istanbul 34295, Turkey. 
On the other hand, when examining international financial reporting standards, although fair value also is suggested in the conceptual framework and related standards, measurement is being used instead of the valuation. From this point of view, specific to business combinations, in determining the fair value of the acquired business, valuation is required beyond the measurement of non-monetary items as well as monetary ones in the financial statements.

International Valuation Standards are predicated on valuation which is updated with improvements made on a large scale on 19 July 2011 and in July 2013 after making minor corrections in the standards to be effective from January 2014. Even if these standards are not adopted by the International Accounting Standards Board (IASB), they are taken as a reference when the valuation is made for financial reporting within the scope of IFRS.

There are uncertainties on, how to determine the value of the acquiree in a business combination and how to measure the value reported under IFRS as well as the place of IVS in this measurement and valuation. In this context, in this study it emphasized the necessity of carrying out valuation activities according to International Valuation Standards, which would be needed in preparation of their financial statements within the framework of the values stated in IFRS. This study aims to determine the fair value of the acquiree in the most suitable way in practice by showing the effects created by the differences in the case of business combination application.

It is stated in IFRS 3 that all business combinations are accounted for using the purchase method. In addition, considering the measurement of identifiable assets and liabilities, there is also need to determine the fair value.

During the acquisition of a business, considering the non-existence of the company substitutes for each other in market conditions, it is necessary to determine the fair value of the acquiree from the acquirer's point of view, rather than the market value. For example, the market value is determined by market participants who can be easily substituted in each of the same brand and model of vehicles in the second-hand car market, the market value can be equal to the fair value. However, when business is concerned, parameters such as the position in the industry, brand awareness, intellectual capital, and geography are all considered, therefore fair value cannot be expected to be equal to market value which simply consists of market participants.

Hence, it raises the need to identify the individual special value of identifiable assets and liabilities acquired in the business combination for each potential acquirer. Thus, the value attributed to the acquired company's approach to the acquirer beyond the market value may be a more accurate assessment of the true determination of fair value.

\section{Overview of Basic Concepts}

\section{Value and Valuation}

Value is an economic concept for purchasing goods or services which represents price that is created between buyer and vendors (Vol: VIII, No: 45, 2006). The value of an asset depends on many factors and opens to change over time in accordance with the economic environment, the potential area of utilization and position, timing of the performed appraisal, replacement value, shareholding structure, liquidity of asset, market and physical condition (Miller, 1995).

Valuation is required producing reliable results of operations and performed a detailed analysis based on prior data (Berk, 2010). It is necessary to determine a date for the valuation. Sometimes, the entity's fiscal year end is stated in the valuation contracts as a simplistical Valuation Date (Laro \& Pratt, 2005). 
The concept of value and distribution always maintained its importance from past to present. Determining the value will also maintain its importance in the future as well with the awareness of investors and with increasingly more sensitive methods (Berk, 2010).

\section{Value Approach and Process}

The valuation approaches are generally divided into four categories. These are indicated as follows (Damodaran, 1996):

- Asset-based approach,

- Market-based approach,

- Cash flow-based approach,

- Residual income based approach.

On the other hand, the valuation process usually consists of following five steps (Pinto, Henry, Robinson, \& Stowe, 2010):

- Understanding operations of the business,

- Estimating the performance of company,

- Selecting the appropriate valuation method,

- Converting the assumptions to a valuation,

- Applying the valuation results.

\section{Comparison of International Valuation Standards and International Financial Reporting Standards in Terms of Valuation}

\section{Approaches to Valuation Basis in IVS}

In this section, the three main approaches in IVS to determine the value of an asset: market, income, and cost based approaches are briefly explained.

\section{Market Approach}

Market value is defined in the standards:

The estimated amount for which an asset or liability should exchange on the valuation date between a willing buyer and a willing seller in an arm's length transaction, after proper marketing and where the parties had each acted knowledgeably, prudently and without compulsion. (Vol: VIII, No. 45, 2006)

The market-based valuation approach provides an indication of value by comparing the subject asset with identical or similar assets accessible price information (IVS, Framework, 2013).

\section{Income Approach}

Income approach is defined in IVS that converted the future cash flows to a single current capital value (IVS, Definitions, 2013). Income approach method is included that capitalization of income where an all risks or overall capitalization rate is applied to a representative single period income, discounted cash flow where a discount rate is applied to serials of cash flows for future periods to discount them to a present value and various option pricing models (IVS, Framework, 2013).

Income approach considers free cash flow generated potential profitability or potentially created free cash flows in the future and tries to determine the amount, to predict and discount the net free cash flows to the net present value (Abrams, 2010). 


\section{Cost Approach}

The cost approach provides an indication of value using the economic principles that a buyer will pay no more for an asset than the cost to obtain an asset of equal utility, whether by purchase or by construction. This approach is based on the principle that the price that a buyer in the market would pay for the asset being valued would, unless undue time, inconvenience, risk or other factors are involved, be not more than the cost to purchase or construct an equivalent asset (IVS, Framework, 2013).

Some provisions are deducted using a variety of depreciation methods for estimating an asset's price which is approximately market value. Cost approach can provide a direct indicator of market value depending on the scope of existing data for calculations (Vol: VIII, No: 45, 2006).

\section{Approaches to Valuation Basis in IFRS}

Items recognized the historical value in the financial statements have the purchasing power of money in different dates. Therefore, an asset acquired in previous periods or paid capital for many years ago, shows the value lower than it should be in balance sheet (Gökçen, 2004).

The valuation bases of financial statement elements, which are historical cost, current cost, realizable value, and present value, are classified in four major topics in the framework of International Financial Reporting Standards (IFRS, Conceptual Framework for Financial Reporting).

Furthermore, frequently emphasizing the concept of fair value in standards, is expressed assets and liabilities to be measured realistically, causes the best way to fulfil users' information needs. In this context, regarding the valuation of the financial statements elements in standards, there are five major valuation approaches. These are shown in the below list (Akbulut, 2008):

- Historical cost,

- Current value,

- Realizable value,

- Present value,

- Fair value.

\section{Historical Cost Approach}

Generally financial statements are prepared within the frame of an accounting model primarily based on the concept of recoverable historical cost and the maintenance of nominal invested capital (IFRS, Conceptual Framework for Financial Reporting). Historical cost is defined in conceptual framework as in the following statement: "Assets are measured by the amount of cash or cash equivalents paid or the fair value of the exchanged assets" (IFRS, Conceptual Framework for Financial Reporting).

\section{Current Value Approach}

The basic premise of this approach is the current purchase price. Although assets and liabilities are aimed to show in the financial statements with their fair value at the balance sheet date, difficulties in determining the scope of the assets and liabilities and impossibility of determining the current cost of related assets and liabilities restrict applying it (Kahraman, 2006). Current cost itself is usually defined using as a valuation method: choose replacement cost or recoverable amount, whichever is the lower (Whittington, 1994).

\section{Realizable Value Approach}

Under normal operational conditions of the company, the asset's value is equal to cash and cash 
equivalents amount which will be recovered in the disposal of an asset (IFRS, Conceptual Framework for Financial Reporting). When the realizable value basis is compared to the current cost basis, current cost basis is based on the presumptive purchase as for that the realizable value basis is based on the presumptive selling approach (Tokay \& Deran, 2008).

\section{Present Value Approach}

The carrying amount of the affected assets exceeded the higher of the present value of their estimated future cash flows and fair value less costs to sell (Ankarath, Mehta, Ghosh, \& Alkafaji, 2010). Under normal operational conditions of the company, the assets are presented with their present values discounted of future cash flows. The liabilities, under normal operational conditions of the company, are represented by the discounted present value of net cash outflows to be paid in the future (IFRS, Conceptual Framework for Financial Reporting).

\section{Fair Value Approach}

In IFRS 3, it is stated that the acquirer shall identify the acquisition date, which is the date on which it obtains control of the acquiree and measure, separately from goodwill, the identifiable assets acquired, the liabilities assumed at their acquisition-date fair values. Fair value is defined and framework is determined for the measurement in IFRS 13 Fair Value Measurement (Demir \& Bahadır, 2007).

\section{Valuation Methods in International Financial Reporting Systems (IFRS)}

Fair value, Market value, Investment value, Special value, and Specific value are classified as measurement methods in the IFRS. Particularly, methods of investment value, special value, and specific value are different from those methods stated in IVS.

\section{Fair Value}

IVS based fair value is defined as possible price for transferring an asset or for discharging of debt between respective, identifiable, well informed and willing/aspirant sides. However, this definition is different from what is stated in IFRS. IVS considers "value" to be overlapping with and suitable to the market value. Fair value definition and its implementation based on IFRS are explained in detail under IVS 300 Valuation Standards for Financial Reporting (IVS Framework, 2013).

IVS includes some reference points to IFRS 13, the same as IFRS does. IVS underlines point of differences in defining fair value. IVS signals a fair price attributed to both sides. Yet, IVS based market value is matching of IFRS based fair value. In terminological sense, this causes confusion for decision makers and information users regarding valuation applications for financial reporting.

\section{Market Value}

IVS based market value is defined in accordance with market conditions transferring an asset or discharging of debt, as value determined between knowledgeable, eager and prudent sides (acquiring and acquire company) as a result of bargaining that is far from any pressure (IVS Definitions).

\section{Investment Value}

Investment value is defined as an attributed value considered for owner or potential owner with an aim of individual investment and/or operational activities (stated in IVS Definitions).

This subjective concept associates an asset with an investor, group of investors, or an institution that have identifiable investment objectives and/or some objective criteria (Vol: VIII, No: 45, 46). 


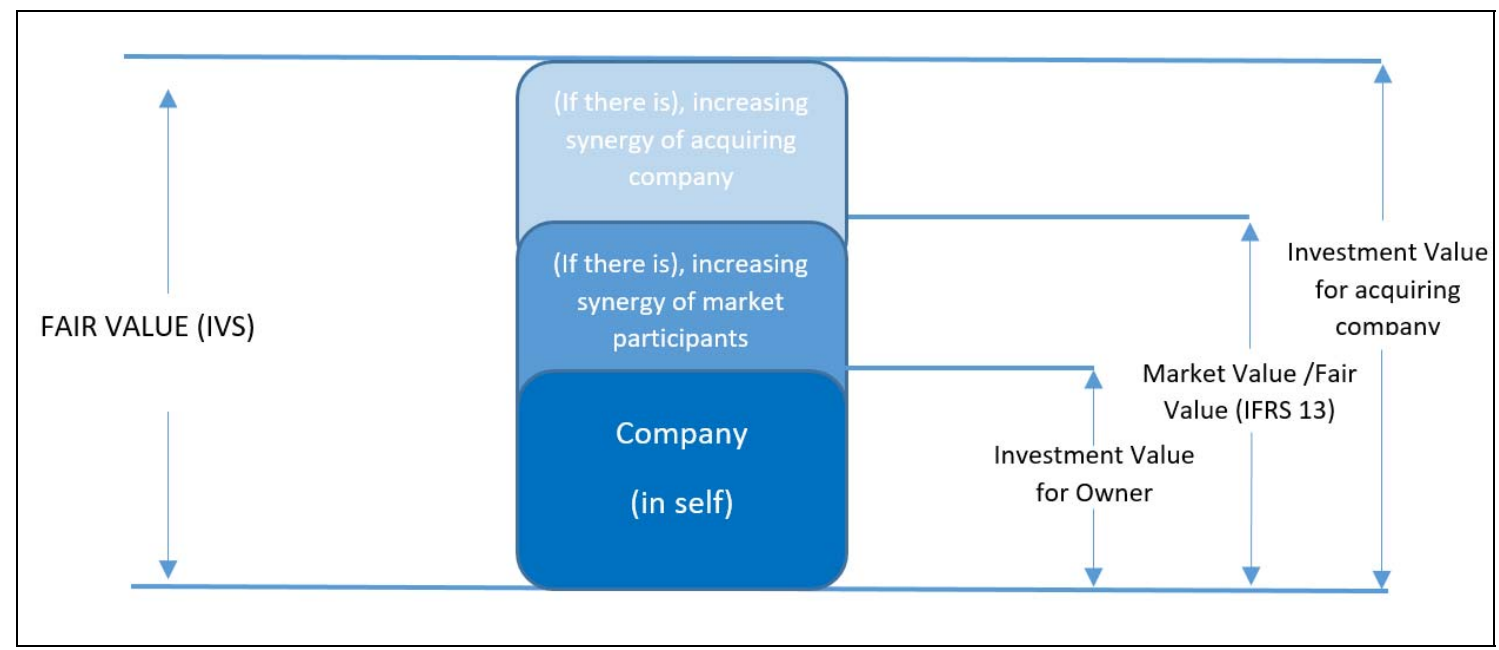

Figure 1. An analysis of possible financial information constituting fair value guidelines (IVSC, Illustrative Examples, Chapter 1 -base of value).

\section{Special Value}

Specific value with particular features refers an amount attributed only to special purchaser. This purchaser is eager to purchase an asset from a specific value for advantages that are generated from ownership, which is null and void for other purchasers in the market (IVS Framework).

Specific value emanates from taking an attention of a particular purchaser other than the other(s) in the market. Market value does not consider any dimension of a specific value. Since, specific value is not for an eager purchaser, it is an attributed value for a determined purchaser in a determined date of purchasing (IVS Framework).

\section{Synergistic Value}

Synergistic value is an additional factor resulting from combination of one or more assets or rights value in which those combined value is higher than their total respective values (IVS Framework). It is also defined as increase in value derived from combination of two or more rights of an asset (Vol: VIII, No: 45, 178).

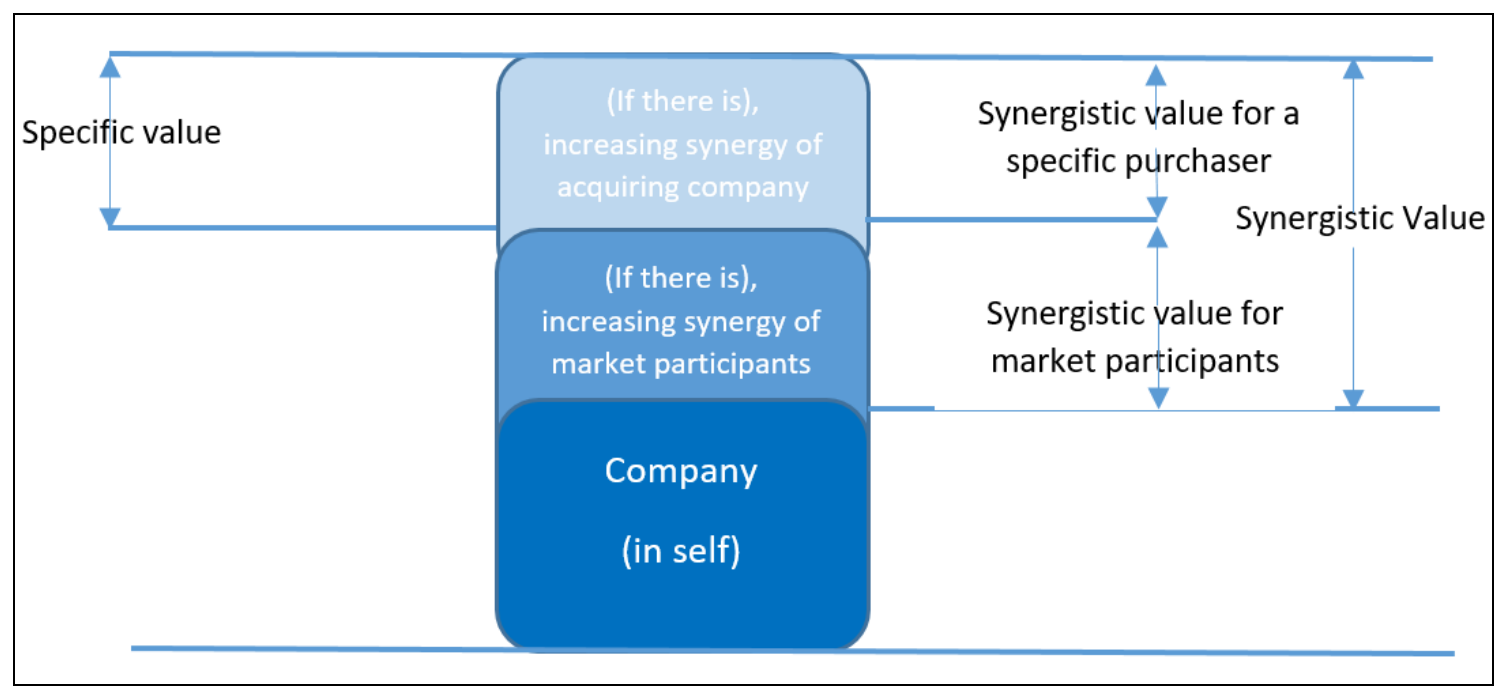

Figure 2. Relationship between synergistic and specific value (IVSC, Illustrative Examples, Chapter 1-base of value). 


\section{Depreciation Based Replacement Cost of an Asset}

Depreciation based replacement cost of an asset, is an application of cost method for appraising value of exclusive assets under conditions of inadequate evidence or supporting materials in the market (Vol: VIII, No: $45,126)$. It implies an amount calculated after discounting all kind of impairments such as physical depreciation and being outmoded and renewing costs from cost of production of the same asset or change for a new one (Shapiro, Mackmin, \& Sams, 2013).

\section{Research Method}

\section{Aim of the Study}

In this section, the importance of determining company's value in accordance with financial reporting in business combinations, is particularly emphasized. Main aim is to unravel the differences in determining the value of the firm in question based on IFRS and IVS.

According to IFRS No. 3 of Business Combination, it is ensured that identifiable assets and assumed identifiable liabilities are measured based on their fair values. This study's main concern is on a difference between IVS and IFRS 13 Fair Value Measurement in terms of fair value. Thus, there is a need to determine the fair value of acquired firm under conditions of business combinations.

\section{Case Companies Combination}

In the following part, it is shown that how acquiring business named $\mathrm{ABC}$ prepares financial tables in consequence of the combination with XYZ under the IVS framework.

$$
\begin{array}{ll}
\text { Acquiring Company } & =\mathrm{ABC} \\
\text { Acquired Company } & =\mathrm{XYZ} \\
\text { Date of combination } & =31.12 .2014
\end{array}
$$

$\mathrm{ABC}$ has decided on a combination with $\mathrm{XYZ}$ as of the date of 31.12.2014 which distributes products that are produced by ABC. Codified Financial Tables of XYZ are prepared subject to the conditions of IFRS in order to determine the fair value of assignee-XYZ. Main differences are identified by making comparisons between financial tables prepared upon combination and those tables based on IVS by determining fair value of XYZ's assets. In this sense, based on related differences it is discussed that fair value presentation principle stated in the framework of IFRS requires determining presentation of fair value in the light of IVS as of the date of balance sheet.

\section{Determining Market Value of Acquired XYZ}

Valuation report of XYZ has been prepared by authorized auditing company regarding such combination. Valuation report dated 15.02.2015, value of the XYZ company has been determined as 650,000 TRY. Referring to valuation report, $100 \%$ stocks of XYZ has been transferred to ABC with 650,000 TRY (purchasing price). Capital of acquired company is 500,000 TRY and nominal value of stocks is 500,000 TRY. However, stockholder's equity of XYZ is 191,020 TRY as the date of 31.12.2014.

Net book value and discounted cash flow methods are used in the report. Among these methods, valuation expert determined the market value of $\mathrm{XYZ}$ as $650,000 \mathrm{TRY}$, which is calculated by using discounted cash flow method.

\section{Synergistic Value of Acquired Company XYZ}

$\mathrm{XYZ}$ classified its building, which gained leasing revenue, as an investment property in financial 
statements and make valuation in by using cost model. Depreciated amount of building in question that was purchased at cost of 150,000 TRY, is 30,000 at the date of acquisition. Market value of fixed properties whose net booking value is 120,000 TRY has been determined as 500,000 TRY in the report.

Table 1

Fair Value of Identifiable Assets and Liabilities Acquired by ABC as the Date of Combination

\begin{tabular}{|c|c|}
\hline & 31.12.2014 \\
\hline Cash and cash equivalents & 14,875 \\
\hline Accounts receivables & 233,465 \\
\hline Other receivables & 2,350 \\
\hline Inventories & 12,355 \\
\hline Prepaid expenses & 8,650 \\
\hline Other current assests & 3,500 \\
\hline Investment properties & 500,000 \\
\hline Fixed assets & 524,360 \\
\hline Intangible fixed assets & 21,000 \\
\hline Short-term liabilities & $(139,435)$ \\
\hline Accounts payables & $(329,470)$ \\
\hline Employee benefits liabilities & $(15,430)$ \\
\hline Other liabilities & $(5,640)$ \\
\hline Provision for other liabilities and expenses & $(1,200)$ \\
\hline Other short-term liabilities & $(2,135)$ \\
\hline Long-term liabilities & $(189,655)$ \\
\hline Long-term provisions for employee benefits & $(96,120)$ \\
\hline Deferred tax liabilities & $(46,450)$ \\
\hline Fair value of total identifiable net assets & 495,020 \\
\hline Purchasing price & 650,000 \\
\hline Difference between purchasing price and fair value of net assets & 154,980 \\
\hline Acquired net assets & 495,020 \\
\hline Acquired liabilities & $(650,000)$ \\
\hline Purchased cash and cash equivalents & 14,875 \\
\hline Total purchasing price & $(635,125)$ \\
\hline Goodwill acquired from combination & 154,980 \\
\hline
\end{tabular}

In accordance with IVS, market value of such properties is market value determined by a valuation expert under free market conditions. Such value is considered fair one in accordance with IFRS. On the other hand, IVS framework accepts fair value that is different from market value.

Property in question is run by a leaser as a local brand hotel. It is clear that this location could increase its value, because there is a possibility of future purchasing by an international hotel chain. Valuation expert is using performance indicators of similar hotels, retrospective performance indicators of the hotel and market indicators to determine the value. Possible purchasing company could run this business more effectively with synergy of running other hotels; as a result, it is more likely that higher cash flow could be generated. Thus, from this perspective, investment value would be different from market value. In addition, it is predicted that revenue would increase swiftly due to the increasing number of rooms and beds after acquisition of property which is carried out valuation and also four-star hotel would increase to five-star and biggest 
competitor may be removed as well. That's why special value to the business near the hotel is much more different than market value.

The effect of possible buyers of international hotel chain and a hotel near to it will impact on determination of the fair value of such property. Such determined value will be different from its market value.

Value of company XYZ that is the main distributor of $\mathrm{ABC}$ has been determined as 650,000 TRY by a valuation expert. This is just reflecting the market value considering XYZ's assets, liabilities, and free cash flows generated in the future.

ABC will save 50,000 TRY as a result of consolidated general administrative expenses of XYZ. For instance, due to ERP used by ABC, there is no need for accounting department in the company, any accounting software system supporting expenses and accounting staff expenses will be eliminated. Expenses from Certified Public Accountant (CPA) and tax consulting services will also decrease. It is assumed that using same distribution channels and decreasing inventory costs will cause 20,000 TRY decreases in marketing, purchasing, and distribution expenses.

$\mathrm{ABC}$ plans to run the business from that $\mathrm{XYZ}$ earns rent, as retail store due to its central location. Also, this retail store will create high profitability for $\mathrm{ABC}$ and 250,000 TRY incomes will be generated as a result of discounted leasing and store administrative expenses.

It envisages that residual expenses coming from production will decrease because of developed know-how by $\mathrm{XYZ}$, thanks to the fact that this productivity will increase. This will yield revenue of 70,000 TRY. This know-how is also regarded as positive contribution for other market participants and also yields same revenue for them.

Investment value defined in the IVS will be determined by assuming $\mathrm{ABC}$ as a specific acquiring company and as of the date 31.12.2014 its value is 10,000,000 TRY. Investment value of such combined companies is calculated as follows:

Table 2

Investment Value Calculation

\begin{tabular}{ll}
\hline Market value of XYZ & 650,000 \\
\hline Savings from general administrative expenses & 50,000 \\
Savings from marketing, purchasing and distributing expenses & 20,000 \\
Profitability of operating retail store & 250,000 \\
Increase in productivity & 70,000 \\
Market value of ABC & $10,000,000$ \\
Combined value of both companies for specific acquiring business & $11,040,000$ \\
\hline
\end{tabular}

IVS Defined 390,000 Synergistic Value is calculated as follows:

Table 3

Synergistic Value Calculation

\begin{tabular}{cl}
\hline Combined investment value of two companies for specific acquiring company & $11,040,000$ \\
\hline Market value of ABC (-) & $(10,000,000)$ \\
Market value of XYZ (-) & $(650,000)$ \\
Synergistic value for acquiring company & 390,000 \\
\hline
\end{tabular}

\section{Determining Acquired Company's Fair and Market Value Based on IVS}

According to IVS, fair value becomes evident as a result of combined market value of an asset in question 
and synergistic value in terms of acquiring company. From this point, IFRS and IVS become different in determining fair value. IFRS based fair value is argued to be same as IVS based market value.

Following table shows how to calculate fair and market value based on IVS.

Table 4

Fair and Market Value of XYZ Based on IVS

\begin{tabular}{ll}
\hline Market value of XYZ (a) & 650,000 \\
\hline Savings from general administrative expenses & 50,000 \\
Increase in productivity & 70,000 \\
Synergistic value for acquiring company as market participant $(b)$ & 120,000 \\
Savings from marketing, purchasing and distribution expenses & 20,000 \\
Profitability of operating retail store & 250,000 \\
Specific synergistic value (c) & 270,000 \\
Total synergistic value for acquiring company $(\mathrm{b}+\mathrm{c})$ & 390,000 \\
Fair value (from IVS) $(\mathrm{a}+\mathrm{b}+\mathrm{c})$ & $1,040,000$ \\
Market value (from IVS) $(\mathrm{a}+\mathrm{b})$ & 770,000
\end{tabular}

\section{Discussion and Conclusion}

International Valuation Standards are predicated on valuation which is updated with improvements made on a large scale on 19 July 2011 and in July 2013 after making minor corrections in the standards to be effective from January 2014. Even if these standards are not adopted by the International Accounting Standards Board (IASB), they are taken as a reference when the valuation is made for financial reporting within the scope of International Financial Reporting Standards (IFRS).

The main reason of difference between IFRS and IVS based fair value of acquired business is that IFRS based fair value is considered market value in the IVS. In the IVS, instead of traditional market value, different approaches are used for determining more appropriate fair value.

In IFRS 13 Fair Value Measurement, aim of using such valuation method is defined as determining price in transaction that is carried out in the date of measurement for transferring an asset or liability under current market conditions between market participants. In IVS 300, it is stated that fair value requires an evaluated price whose advantages and disadvantages are separately analyzed as operating results among pre-determined sides. It is applied under fair conditions. In contrast, what kind of advantages provided for market participants is mostly ignored. Fair value is more comprehensive concept in comparing with market value, because it includes mostly unnoticed factors (IVS Framework, 2013).

In general sense, market value of acquired business in question is determined by an expert with a report. However, in this study, in addition to market value, investment value, special value, and synergistic value are explained under IVS Framework, and determining fair value in consistent such a framework is also discussed.

The purchase decision and the purchase price are assumed to be based on the fair value which is determined in the appraisal report. Thus, indeed IFRS based fair value is identified as equivalent to market value in accordance with IVS.

Business combination is defined as coming two firms together to form a separate reporting department. Under IFRS No. 3, business combinations are recognized upon the method of purchasing (It is stated in IFRS 3 that all business combinations are accounted for using the purchase method). 
At the same time, in IFRS 3 it is stated that purchasing price is accounted for determining not only fair values of identifiable assets, liabilities, unconditional liabilities but also fair values of intangible fixed assets that are not included in the financial tables of acquired business before, in the date of acquisition.

Effects of different valuation approaches towards recognizing and reporting such combination are also shown in consolidated statement of financial position.

The acquisition costs are incurred and the business acquired by the acquirer, acquired identifiable assets, liabilities and conditional liabilities exceeding fair value is accounted for goodwill on the acquisition date in the non-current assets.

It is found that if acquired assets and liabilities are recognized in accordance with IFRS, goodwill comes out during the acquisition. Though, when fair value is determined based on IVS, goodwill is not found, even profitable business combination is realized. This is the result of considered fair value based on IVS Framework, that is the combination of market value of an asset in question and total synergistic value.

In Turkey, company valuation reports are issued by audit firms which are authorized by the capital markets board. Audit firms are deemed to be authorized on the basis that they have the qualifications set out in the communiqué published by the capital markets board and that they have established a corporate finance department in their respective bodies in accordance with the requirements of the relevant communiqué. Authorization will be appropriately given after audit firms which depend on the conditions of existence of the recruitment of the competent valuation expert or experts and other necessary technical information and document infrastructure.

In the business combination, it is possible to study to determine the fair value of the acquired business more realistically. In this context, studies carried out by considering the synergistic value in the determination of fair value could guide the future studies.

\section{References}

Abrams, J. B. (2010). Quantitative business valuation: A mathematical approach for today's professionals. Hoboken, NJ: Wiley.

Akbulut, Y. Ö. (2008). Vergi Usul Kanunundaki Değerleme Hükümlerinin Türkiye Finansal Raporlama Standartları Kapsamında

Değerlendirilmesi. Ankara Serbest Muhasebeci Mali Müşavirler Odası Muhasebe Uygulamaları ve Vergi Mevzuatı Sempozyumu Bildiriler Kitabı, 59, 1-31.

Ankarath, N., Mehta, K. J., Ghosh, T. P., \& Alkafaji, Y. A. (2010). Understanding IFRS fundamentals. Hoboken, NJ: Wiley.

Berk, N. (2010). Finansal Yönetim (10th ed.). Istanbul: Türkmen Kitabevi.

Damodaran, A. (1996). Investment valuation. New York, NY: Wiley.

Demir, V., \& Bahadır, O. (2007). UFRS (TFRS)' deki Değerleme Ölçüleri Kapsamında Şirket Değerlemesinde Defter Değeri Yaklaşımı., Muhasebe ve Denetime Bakış Dergisi, 23, 65-79.

Gökçen, G. (2004). Enflasyonun Mali Tablolar Analizine Etkileri. Mali Çözüm, 69, 14-25.

IAS/IFRS. Conceptual framework for financial reporting. Retrieved from http://www.kgk.gov.tr/contents/files/TFRS_2014/F_R_I_K_C(1).pdf

International Valuation Standards. (2013). Framework. Retrieved from http://standards.ivsonline.org/mod/page/view.php?id=108

International Valuation Standards Council. Illustrative Examples. Chapter 1-Base of Value. Retrieved from http://www.ivsc.org/sites/default/files/Exposure\%20Draft\%20Jan\%2014.pdf

International Valuation $\quad$ Standards. (2013). IVS definitions. Retrieved from http://standards.ivsonline.org/mod/glossary/view.php?id=107

Kahraman, O. (2006). Uluslararası Finansal Raporlama Standartlarındaki Değerleme Ölçüleri. Vergi Dünyası Dergisi, $296,60-70$. Laro, D., \& Pratt, S. P. (2005). Business valuation and taxes: Procedure, law and perspective. Hoboken, NJ: Wiley.

Miller, W. D. (1995). Commercial bank valuation. New York, NJ: Wiley. 
Pinto, J. E., Henry, E., Robinson, T. R., \& Stowe, J. D. (2010). Equity asset valuation (2nd ed.). Hoboken, NJ: Wiley.

Sermaye Piyasasında Uluslararası Değerleme Standartları Hakkında Tebliğ. (2006). VIII(45). Retrieved from http://www.spk.gov.tr/displayfile.aspx?action=displayfile\&pageid $=591 \& \mathrm{fn}=\ldots$

Tokay, S. H., \& Deran, A. (2008). Türkiye Muhasebe ve Finansal Raporlama Standartları'nda Değerleme Ölçüleri. Mali Çözüm Dergisi, 90, 15-47.

Whittington, G. (1994). Current cost accounting: Its role in regulated utilities. Fiscal Studies, 15, 88-101. Retrieved from http://www.ifs.org.uk/fs/articles/whitting_nov94.pdf?origin=publication_detail 